\title{
An uncertain future for the endemic Galliformes of the Caucasus
}

\author{
Anouschka R. Hof ${ }^{a, b, *}$, Andrew M. Allen ${ }^{c}$ \\ a Resource Ecology Group, Wageningen University, Droevendaalsesteeg 3, 6708 PB, Wageningen, the Netherlands \\ b Department of Wildlife, Fish, and Environmental Studies, Swedish University of Agricultural Sciences, Umeå 90183, Sweden \\ c Radboud University, Department of Animal Ecology and Physiology, NL - 6500, GL, Nijmegen, the Netherlands
}

\section{H I G H L I G H T S}

- Climate and land use change impacts were investigated for two endemic Galliformes.

- Future suitable geographic ranges were predicted to significantly shrink.

- Both species were "most vulnerable" to climate change in a vulnerability matrix.

- Urgent action is needed to preserve these flagship galliformes of the Caucasus.

\section{G R A P H I C A L A B S T R A C T}
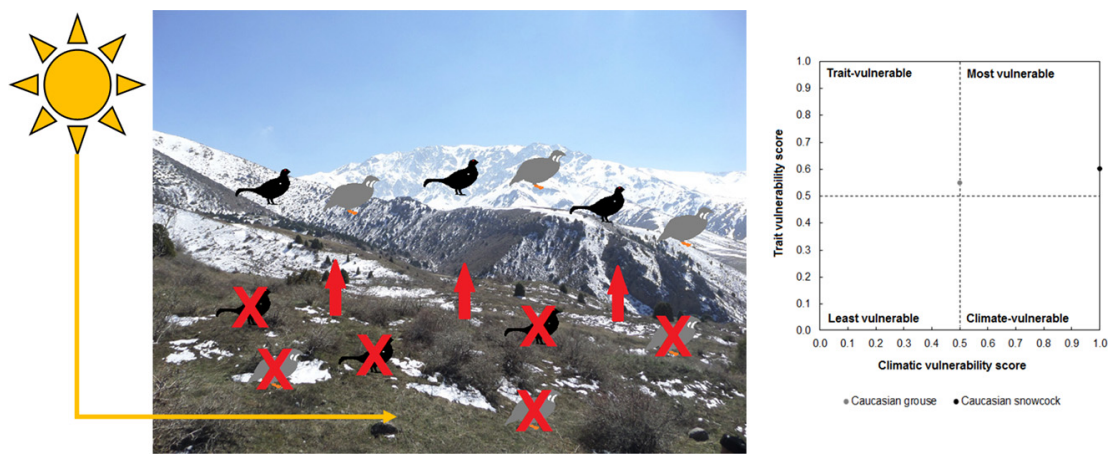

\begin{abstract}
A B S T R A C T
Impacts of climate change are already evident in ecosystems worldwide. High-latitude and altitude regions are at greatest risk because the effects of climate change are greater in these regions, and species from these areas have limited ability to track their climate envelopes. The Caucasian snowcock (Tetraogallus caucasicus) and the Caucasian grouse (Lyrurus mlokosiewiczi) are both high-altitude specialists that are endemic to a restricted range in the Caucasus mountains of Europe. Little research has been performed to determine the status of the populations or the potential impacts of climate change. We investigated how climate and land use change may impact both species in future and determined whether their life history traits may increase their vulnerability using a combined exposure and trait-based index. We compared several climate models, and in all instances, both species showed drastic range contractions although the extent of the contraction varied with each model. Traits like habitat specialism, ground nesting and incubation period meant that both species may be considered "most vulnerable" in the exposure and trait-based index. Given that both species already occur near the maximum elevations of the Caucasus, and that they lack any dispersal capabilities due to the isolation from alternative mountainous areas, research efforts need to be prioritized to improve our knowledge about their population status, to monitor future trends and to begin developing species action plans that conserve these endemic and iconic species of Europe. Both species are flagship and umbrella species and may serve as indicator species, their protection may therefore benefit a whole range of other species inhabiting this vulnerable Alpine ecosystem. Especially the Caucasian grouse has a high aesthetic value and is favoured by hunters in the region. The potential demise of this species may therefore also be negative for local communities.
\end{abstract}

(c) 2018 Elsevier B.V. All rights reserved.

\footnotetext{
* Corresponding author at: Resource Ecology Group, Wageningen University, Droevendaalsesteeg 3, 6708 PB Wageningen, the Netherlands. E-mail address: Anouschka.Hof@wur.nl (A.R. Hof).
} 


\section{Introduction}

Climate change is expected to affect many species, be it in their abundance, distribution, phenology or physiology (Sala et al., 2000; Thomas et al., 2004; Urban, 2015). With ongoing climate change, climate niches are generally shifting to higher latitudes and altitudes and are becoming dissimilar compared to previous conditions (Williams et al., 2007). The survival of species is therefore dependent on their capacity to adapt to new climates or to track their current climatic niches (Parmesan et al., 1999; Walther et al., 2002). Species that inhabit high-latitude regions and mountain ecosystems are predicted to be affected more by climate change than species inhabiting many other ecosystems (ACIA, 2004, IPCC, 2013). Species occurring in these ecosystems have adapted to climates that in future will either have severely reduced geographically or will no longer exist. The rate of increase of temperatures in mountainous areas is for instance projected to be up to three times higher than the rate of increase recorded during the past century (Nogués-Bravo et al., 2007). Studies predict that especially the species adapted to conditions at higher elevations will be threatened by changes in temperature and precipitation regimes (Engler et al., 2011) and mountainous areas throughout the world are already affected by climate change (Pounds et al., 1999; Engler et al., 2011).

Mountain ecosystems are frequently considered as biodiversity hotspots (Orme et al., 2005) meaning that the negative effects of climatic change on these ecosystems may impact a disproportionate number of species. Furthermore, the number of endemic species generally increases with increasing elevation (Kessler, 2002; Vetaas and Grytnes, 2002; Fu et al., 2006), species endemic to high elevations may therefore be at greater risk of extinction. Therefore, a relatively large proportion of endemic species are predicted to go extinct in future due to climate change (Malcolm et al., 2006; Thuiller et al., 2006). In addition to exposure to climate change, several natural history traits of, amongst others, high elevation species, such as thermal tolerance, rarity, habitat specialism and ground nesting behaviour (Deutsch et al., 2008; Foden et al., 2013; Hof et al., 2017), may also make them increasingly vulnerable to climate change.

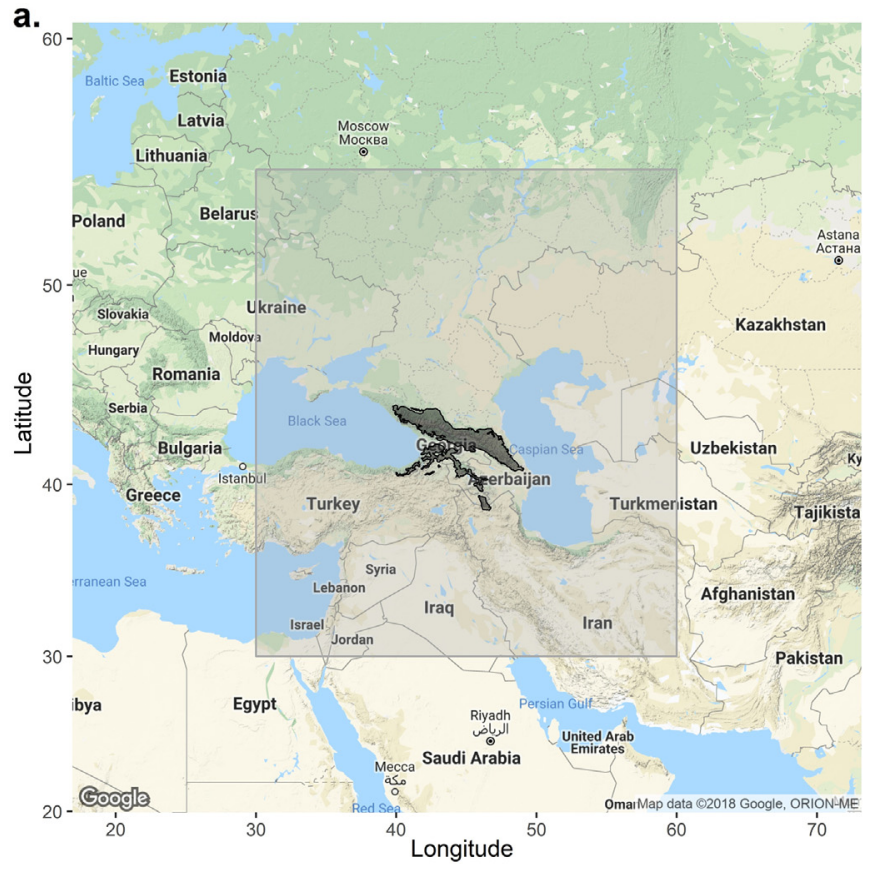

The Caucasian grouse (Lyrurus mlokosiewiczi, henceforth referred to as grouse) and the Caucasian snowcock (Tetraogallus caucasicus, henceforth referred to as snowcock) are two of the few endemic European bird species. Both species are so-called flagship and umbrella species in the Caucasus, which means that their protection could benefit other species that share the same habitat and threats (Roberge and Angelstam, 2004; Zazanashvili and Mallon, 2009). The grouse is currently assessed as Near Threatened on the IUCN red list of threatened species (BirdLife International, 2016). Its distribution range comprises around $321,000 \mathrm{~km}^{2}$ according to BirdLife International (2016), but considerably lower estimates $\left(12,000 \mathrm{~km}^{2}\right)$ have also been reported (Gokhelashvili et al., 2003). The current population trend of grouse is listed as decreasing due to hunting, overgrazing, wood cutting, and habitat fragmentation (Gokhelashvili et al., 2003; BirdLife International, 2016). The snowcock is currently assessed as Least Concern on the IUCN red list of threatened species (BirdLife International, 2017). The current population trend of snowcock is stable. However, its distribution range is smaller than that of the grouse according to BirdLife International (2017), with a range of around $62,600 \mathrm{~km}^{2}$. Both species are endemic to the Caucasus Mountains (see Fig. 1). The grouse inhabits areas at or near the tree line and prefers open habitat (Gokhelashvili et al., 2003; Gavashelishvili and Javakhishvili, 2010), and the snowcock inhabits alpine slopes between the tree-line and the snow-line (McGowan et al., 2018). Since both species inhabit mountainous regions, which may be strongly affected by climate change in future, and both species have several traits that are associated with increased vulnerability to climate change, it is important to assess their vulnerability to climate change. Some work has been done on the grouse; e.g. its potential distribution in Turkey has been modelled (Gottschalk et al., 2007), and its nesting habitat and landscape requirements have been studied (Gavashelishvili and Javakhishvili, 2010; Habibzadeh et al., 2013). However, to date hardly any research has been done on the snowcock, despite its endemicity (Murray et al., 2015). Both species may well face range contraction and possibly even extinction in a future warmer climate. Since both species are flagship and umbrella species and several other members of the Galliformes have been identified as indicator species, the potential loss of these endemic species may

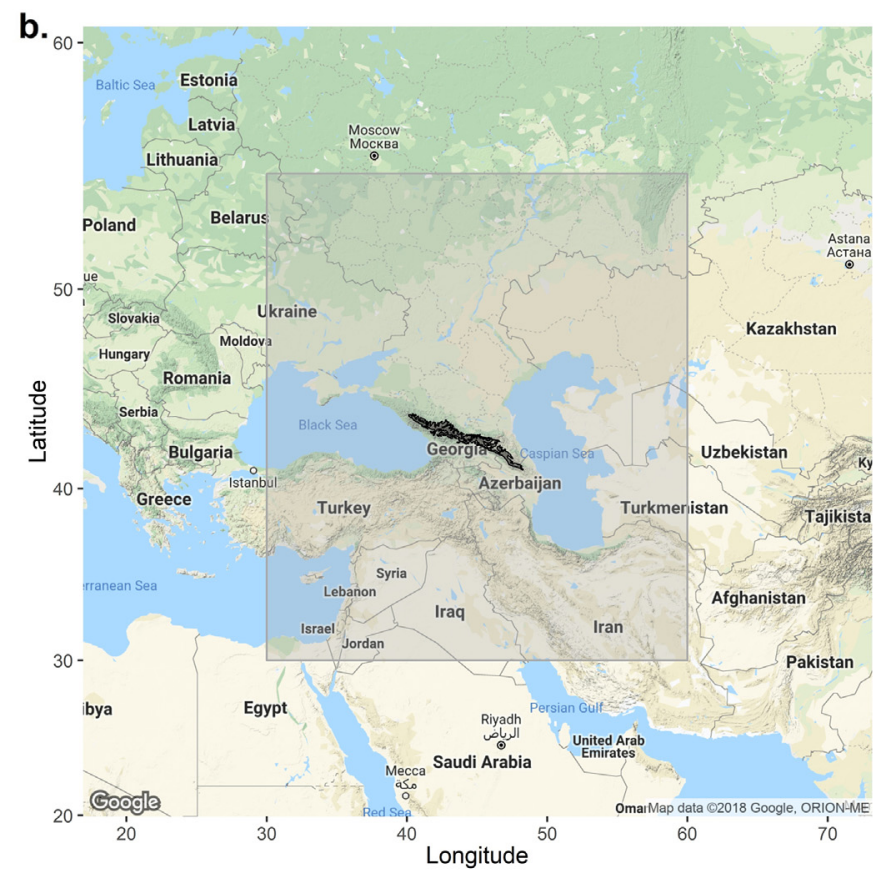

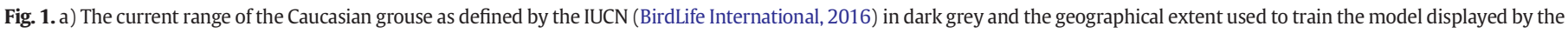

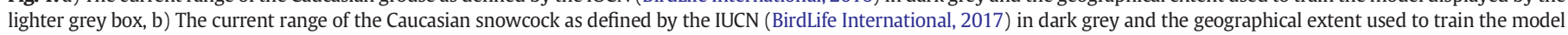
displayed by the lighter grey box. 
indicate that other species inhabiting this already vulnerable alpine ecosystem may also be in peril (Roberge and Angelstam, 2004; Braunisch and Suchant, 2008; Patthey et al., 2008; Zazanashvili and Mallon, 2009). The aim of this study was therefore to assess the vulnerability of both species to climate change.

\section{Material and methods}

We followed the vulnerability matrix for birds that consists of an exposure-index and a trait-index developed by Hof et al. (2017) to assess 1 ) the species' extent of exposure to climate change by predicting the impact of climate change on their current and future potential geographic distribution ranges and subsequently classifying their vulnerability on an exposure-based index, and 2) the species' adaptive capacity and sensitivity to climate change by using a natural-history trait-based vulnerability index.

\subsection{Assessing the extent of exposure to climate change}

The exposure-index is based on 1) the current size of the breeding range in the study region in percentage of the study region (in which $<5 \%$ receives a score of $2,5 \%<x<20 \%$ receives a score of 1 , and $>20 \%$ receives a score of 0 ), 2) the future size (scoring is the same), and 3 ) the amount of stable area, i.e. the percentage of the current breeding range that remains suitable in future (in which $<25 \%$ receives a score of $2,25 \%<x<50 \%$ receives a score of 1 , and $>50 \%$ receives a score of 0 ). Since our study focuses on the entire ranges of both the grouse and the snowcock, it was not necessary to compare the species' current and future "breeding" ranges to a pre-defined study region. Instead, the proportional increase/decrease of the species' ranges from the current to 2070 were included in the exposure-index in which $>0 \%$ increase was scored with 0 points, $0 \%$ to $25 \%$ decrease was scored with 1 point and $>25 \%$ decrease with 2 points. The scoring for stable area however remained the same as in Hof et al. (2017).

\subsubsection{Species distribution modelling}

We used the species distribution modelling algorithm MaxEnt (Phillips et al., 2006) to predict the current and future geographic range of the grouse and snowcock since it is one of the most frequently used species distribution modelling techniques in conservation biology (Rodríguez-Castañeda et al., 2012) and it performs comparably with other methods like boosted regression trees (Elith et al., 2006) and also outperforms many other algorithms (Elith et al., 2006; Hijmans and Graham, 2006). The general approach of MaxEnt is first to identify variables that determine most of the variation in species presence and second to predict the relative suitability of the area for the species to occur, based on the predictor variables entered in the model, throughout a defined region in a specific time (Phillips et al., 2006). The distribution ranges of the species as defined by the IUCN (BirdLife International, 2016, 2017) were used to generate occurrence data - assuming that the species occur throughout the whole range. This is likely going to be an overestimation of the presence of the species but a necessary action due to the limited availability of species occurrences. From these ranges 15,000 occurrences were randomly obtained to enter in the models, using the R package 'dismo' (Hijmans et al., 2017).

The more ecological knowledge we have about a species, the better we can predict its future range. Although predictor variables are often limited to climatic variables, some non-climatic variables can be introduced in predictive models to improve predictions (Araújo and Luoto, 2007; Hof et al., 2012a; Hof, 2015). However, not all factors that are important in determining a species' range can be entered in species distribution models as predictor variables. Unfortunately, future predictions of, for example, food availability are usually not available and can therefore not be used in the models. Predictions generated by species distribution models therefore show the potential niche of a species based on the input variables - e.g. the climatic niche if input variables are limited to climatic variables - and not necessarily the realized niche of a species. Due to such data limitations, we used the 19 bioclimatic variables that are derived from current climatic data (from 1961 to 1990) available at WorldClim (http://worldclim.org/bioclim; Hijmans et al., 2005) to predict the current range of both species at a 30 arc sec scale. We also entered land use data as predictor variables in the models. These data were freely available from the land-use harmonization (LUH) project (Hurtt et al., 2011, http://luh.umd.edu/links.shtml), at a 15 arc min scale, which was transferred to the 30 arc sec scale to match the resolution to the bioclimatic variables. The LUH project has reconstructed land use from 850 to 2015. The historical reconstruction was based on the History Database of the Global Environment (HYDE; Klein Goldewijk et al., 2017) and contains 14 classes of land-use. We averaged the years 1961 to 1990 , as this time-period was used for the bioclimatic variables, to obtain current land use variables. We also entered elevation as a predictor variable in the models. It was not highly correlated $(r<0.80)$ with the other variables. Since it has been found that models excluding elevation generally perform better for mammals (Hof et al., 2012b), we tested the performance of models including elevation and excluding elevation and found that in our case the models that included elevation as a predictor variable performed better.

To assess the suitability of the region in the year 2050 and 2070, we used the same bioclimatic variables derived from several climate projections from downscaled and calibrated global circulation models available at http://www.worldclim.org/ based on the averages for the time-periods 2041-2060 and 2061-2080 (Hijmans et al., 2005); 1) the Community Climate System Model version 4 (CCSM4) developed by the University Corporation for Atmospheric Research, 2) the Norwegian Earth System Model (NorESM1-M), which is based on the CCSM4 but incorporates an isopycnic coordinate ocean model and chemistryaerosol-cloud-radiation interaction schemes (Bentsen et al., 2013), 3) the MIROC-ESM which is based on the global climate model MIROC (Model for Interdisciplinary Research on Climate) that has been cooperatively developed by the University of Tokyo, NIES, and JAMSTEC (Watanabe et al., 2011), 4) the Hadley Centre Global Environment Model version 2 ES (HadGEM2-ES) developed by the Met Office Hadley Centre (Jones et al., 2011), and 5) the Institute of Numerical Mathematics Climate Model version 4 (INMCM4.0) developed at the Institute of Numerical Mathematics of the Russian Academy of Sciences (Volodin et al., 2010), all under the Representative Concentration Pathway (RCP) 8.5. This RCP is characterized by high population growth, relatively slow income growth, modest rates of technological change and energy intensity improvements, that lead to high energy demand and greenhouse gas emissions since climate change policies are largely absent (Riahi et al., 2011). We chose this RCP since it is the worst-case scenario and if more climate change policies will not come into place, the aim of the 2015 Paris Agreement of the United Nations Framework Convention on Climate Change (UNFCCC) to limit the increase in global average temperatures to well below $2{ }^{\circ} \mathrm{C}$ above pre-industrial levels by 2100, may not be reached (Huntingford and Mercado, 2016; Wollenberg et al., 2016). We used the projected changes in land-use developed by the land-use harmonization (LUH) project (Hurtt et al., 2011, http://luh.umd.edu/links.shtml). Different climate change scenarios have been used by the LUH project than by WorldClim. The LUH project developed multiple future scenarios according to the Scenario Model Intercomparison Project (ScenarioMIP; O'Neill et al., 2016) within CMIP6 (Coupled Model Intercomparison Project Phase 6; Eyring et al., 2016) and provided by the Integrated Assessment Models (IAM). Similar to the bioclimatic variables, we extracted future land use under the RCP8.5 scenario which was coupled with the Shared Socioeconomic Pathway 5 (SSP5; Riahi et al., 2017). To replicate the procedure used for the bioclimatic variables, we averaged the time-periods 2041-2060 and 2061-2080 to obtain future land use for 2050 and 2070 respectively. We entered elevation as a static variable in the models. 
Table 1

Predictor variables included in the models for the Caucasian grouse and the Caucasian snowcock.

\begin{tabular}{lll}
\hline Predictor variable & Grouse & Snowcock \\
\hline Annual precipitation & $\mathrm{X}$ & $\mathrm{X}$ \\
Isothermality & $\mathrm{X}$ & $\mathrm{X}$ \\
Maximum temperature of the warmest month & $\mathrm{X}$ & $\mathrm{X}$ \\
Mean diurnal range & $\mathrm{X}$ & $\mathrm{X}$ \\
Precipitation of the driest quarter & $\mathrm{X}$ & \\
Precipitation of the warmest quarter & $\mathrm{X}$ & $\mathrm{X}$ \\
Precipitation of the wettest month & $\mathrm{X}$ & $\mathrm{X}$ \\
Precipitation of the wettest quarter & $\mathrm{X}$ & $\mathrm{X}$ \\
Temperature annual range & $\mathrm{X}$ & $\mathrm{X}$ \\
Temperature seasonality & $\mathrm{X}$ & $\mathrm{X}$ \\
Elevation & $\mathrm{X}$ & \\
Managed pasture & & $\mathrm{X}$ \\
Rangeland & $\mathrm{X}$ & $\mathrm{X}$ \\
Secondary mean biomass density & & \\
\hline
\end{tabular}

MaxEnt minimizes correlation between variables by giving more weight to variables that exhibit high correlation with the occurrence data (Elith et al., 2011). All included variables may be potentially meaningful, but several variables were highly correlated $(r>0.8)$. We therefore limited the predictor variables to those that were amongst the best predictors according to jackknife analyses of variable importance, and that were not highly correlated (Table 1 ). To further avoid under- and over-fitting, which has a negative effect on the predictive performance of models (Phillips and Dudík, 2008), we tuned and evaluated the performance of the regularization multipliers $0,1,2,3$ and 4 and used the multiplier that resulted in the best models (Merow et al., 2013; Radosavljevic and Anderson, 2014) (see Section 2.1.1 for model evaluation).

Model outcome can vary based on the geographical extent used to train the model (Anderson and Raza, 2010), and based upon the order with which variables are entered in the models, which is an automated process carried out by MaxEnt (Elith et al., 2011). Both species are restricted to the Caucasus region. We however extended the geographical extent of the study region by approximately $1000 \mathrm{~km}$ south of the southernmost point of the current distribution range of the snowcock as reported by the IUCN (Fig. 1). This was done to make sure that the breadth of the climatic conditions used to generate the future predictions captured the full climatic niche of the species. Future environmental conditions may not be represented if the geographical extent is restricted to a small region (Thuiller et al., 2004). Furthermore, it may identify potential suitable areas where the species currently are not occurring, such as in the Northern regions of Iran and in Turkey. The models were replicated 30 times, using cross-validation, for each climate scenario to capture model variations and to test whether the total amount of suitable area significantly increased or decreased, using a Welch Two Sample paired $t$-test. MaxEnt uses a continuous scale to predict the suitability of a region which we transformed into binary suitable/unsuitable area by applying a cut-off threshold that was based upon the smallest difference between sensitivity and specificity (Liu et al., 2005).

\subsubsection{Model validation}

The area under the curve (AUC) of a receiver operating characteristic (ROC) plot was used to test the accuracy of the models (Phillips et al., 2006), where an AUC score of 0.500 signifies a random prediction, $>0.500$ a better than random prediction and $<0.500$ a worse than random prediction. Furthermore, we selected $30 \%$ of the occurrence data to set aside as calibration data by means of randomized partition to compare the AUC of the calibration models with those of the training models that consisted of the remaining $70 \%$ of the occurrence data. After models were run, we evaluated model performance by using the calibration dataset to calculate a cumulative binomial probability distribution for the models and obtained a $p$-value of test-significance, based upon recommendations (Peterson et al., 2011). The binomial was based on the number of occurrences in the evaluation dataset that were correctly predicted by the model outcome out of the total number of occurrences in the evaluation dataset (Peterson et al., 2011).

\subsection{Assessing the adaptive capacity and sensitivity to climate change}

The traits-index of Hof et al. (2017) is based on the following traits: migrating, diet breadth, habitat specialist, ground nesting, average clutch size, number of incubation days, number of fledging days, length of the breeding season, typical number of broods, adult survival rates, age at first breeding, and maximum lifespan (for scoring see Hof et al., 2017). We consulted the literature (Cramp et al., 1979; Gokhelashvili et al., 2003) and sources on the internet (http://zverevedia.ru/, http:// www.ebirds.ru/, http://www.egir.ru) to obtain information for as many of these traits as possible, but we were unable to find information with regard to adult survival rates and maximum lifespan. All statistical analyses were conducted in R version 3.3.1 (R Development Core Team, 2016).

\section{Results}

\subsection{Exposure to climate change}

Model performance was fair with a mean AUC of 0.748 and 0.764 respectively and a cumulative binomial probability of $0.992(p<0.001)$ and $0.998(p<0.001)$ for the grouse and the snowcock respectively. The models predicted that both the grouse and the snowcock should, at present, be able to have a larger distribution range than currently outlined by the IUCN based on their climatic niches (Fig. $2 a$ and $b$ ). However, according to all climate change scenarios the potential geographic distribution range of both the grouse and the snowcock will be significantly smaller in future based on climatic variables alone (Table 2). In other words, their climatic niches will shrink significantly. The extent of the loss was however dependent on which climate scenario will be closest to the true change in climatic conditions (Oneway ANOVA, grouse 2050: $\mathrm{F}_{4}=3603, p<0.001$, grouse 2070: $\mathrm{F}_{4}=$ 6116, $p<0.001$, snowcock 2050: $\mathrm{F}_{4}=9022, p<0.001$, snowcock 2070: $\left.F_{4}=97,123, p<0.001\right)$. The INMCM4.0 scenario was most optimistic for both species; this scenario predicted a loss of 'only' 23\% ( \pm 0.46 ) for the grouse in 2050 and even less in $2070(19 \% \pm 0.34)$, and $60 \%( \pm 0.70)$ for the snowcock in 2050 and also less in $2070(45 \% \pm$ 0.48 ) (Table 2). In fact, most of their current range, as outlined by the IUCN, is predicted to remain suitable up to at least 2070 (Figs. 3a, b and $4 \mathrm{a}, \mathrm{b})$. Some additional areas may also become suitable. The MIROC-ESM scenario on the other hand was most pessimistic for the grouse with a predicted loss of $67 \%( \pm 0.46)$ in 2070 (Table 2$)$. Under this climate scenario it is predicted that some of the southern parts of the current range, as outlined by the IUCN, will not be suitable for the species to occur any longer by 2050 (Fig. 3c) and most of the southern parts of its current range will not be suitable any longer by 2070 (Fig. 3d). The HadGEM2-ES and MIROC-ESM scenarios were most pessimistic for the snowcock with both predicting a large loss of suitable area in the region by 2050 and complete loss by 2070 (Table 2, Fig. 4c and d).

The amount of stable area, defined as the percentage of the current range that is still suitable in future, also depended on the climate change scenario (One-way ANOVA, grouse 2050: $\mathrm{F}_{4}=5117, p<0.001$, grouse 2070: $\mathrm{F}_{4}=5935, p<0.001$, snowcock 2050: $\mathrm{F}_{4}=9012, p<0.001$, snowcock 2070: $\left.F_{4}=102,182, p<0.001\right)$. Under the INMCM4.0 scenario, the stable area was generally larger than under the other scenarios. Under the MIROC-ESM scenario, the amount of stable area was the smallest for both the grouse and for the snowcock together with the amount of stable area under the HadGEM2-ES scenario (Table 2).

The predictor variable 'Temperature seasonality' was most important in predicting the climate niche of the grouse, whilst the 'Maximum temperature of the warmest month' was most important in predicting 
a.

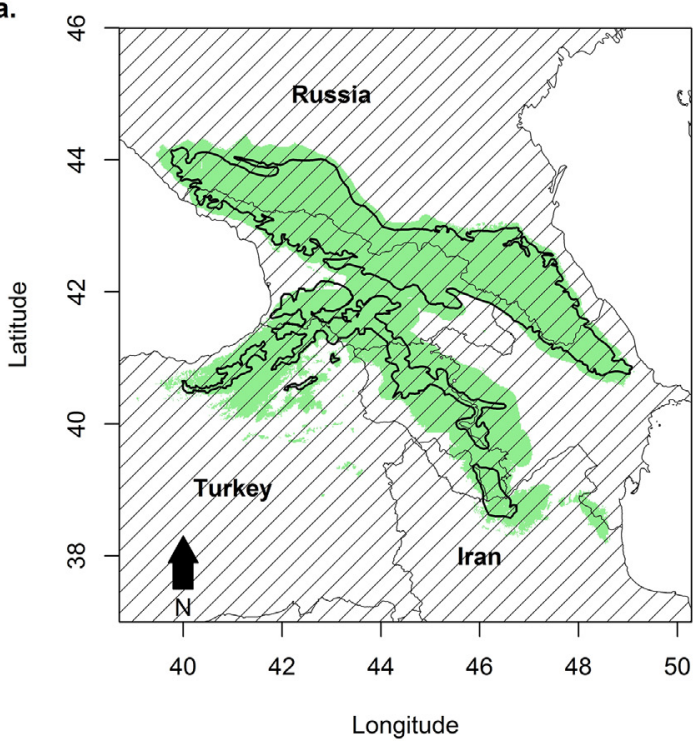

b.

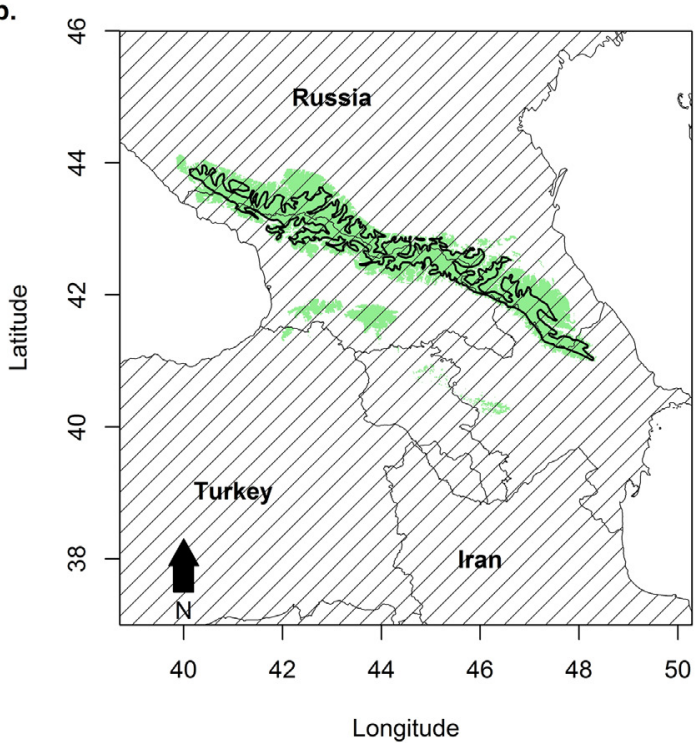

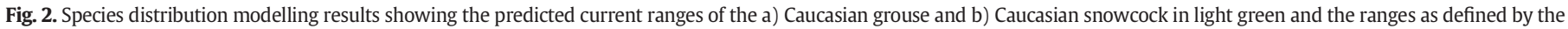
IUCN outlined in bold. (For interpretation of the references to colour in this figure legend, the reader is referred to the web version of this article.)

that of the snowcock (Fig. 5). The second most important predictor variable was for both species the 'Temperature annual range'. The variable temperature seasonality, calculated as the standard deviation of the mean monthly temperatures in degrees' Celsius multiplied by 100 , showed that the grouse was predicted to occur in areas where the temperature seasonality was between approximately 600 and 900 (Fig. 6a). The snowcock was predicted to occur in areas where the maximum temperature of the warmest month was lower than $22^{\circ} \mathrm{C}$ (Fig. 7a). The variable 'Temperature annual range', which is calculated as the maximum temperature of the warmest month minus the minimum temperature of the coldest month in degrees' Celsius multiplied by 100 predicted a high probability of presence of the grouse between approximately 260 to 360 and of the snowcock between 280 and 330 . Changes in land use did not appear to affect the suitability of the area to occur very much for the grouse nor for the snowcock. The only two predictor variables related to land use change appearing in the model for the grouse were 'Managed pasture' and 'Secondary mean biomass density', neither of which were amongst the top predictors. In addition, only two predictor variables related to land use change appeared in the model for the snowcock: 'Rangeland' and 'Secondary mean biomass density'. Also in this model, these predictor variables were not amongst the top predictor variables.

\subsection{The vulnerability matrix}

The scoring for the exposure-index was based on the average over the different climate change scenarios for 2070, which means that the decrease of the range of the grouse was on average $44 \%( \pm 7 \%)$ and the snowcock was on average $86 \%( \pm 21 \%)$, thus both scoring 2 points on the index (Table 3 ). The average percentage of stable area for the grouse was $53 \%( \pm 16 \%)$, and that of the snowcock $14 \%( \pm 21 \%)$. The grouse therefore scores 0 points and the snowcock scores 2 points on the index (Table 3).

Table 2

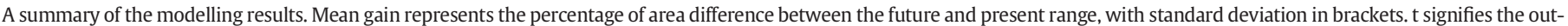
come of the Welch Two Sample paired $t$-tests between the current and future predicted mean percentage of the study region that is suitable ( $\mathrm{df}=29$ for all) and the $p$-values.

\begin{tabular}{|c|c|c|c|c|c|c|}
\hline Scenario & Year & Species & Mean gain (\%) & $t$ & $p$-value & Mean stable area (\%) \\
\hline \multirow[t]{4}{*}{ CCSM4 } & 2050 & grouse & $-25 \%( \pm 0.60)$ & 154.32 & $<0.001$ & $74 \%( \pm 0.61)$ \\
\hline & & snowcock & $-75 \%( \pm 0.62)$ & 28.79 & $<0.001$ & $25 \%( \pm 0.64)$ \\
\hline & 2070 & grouse & $-41 \%( \pm 1.59)$ & 228.02 & $<0.001$ & $57 \%( \pm 1.58)$ \\
\hline & & snowcock & $-92 \%( \pm 0.34)$ & 28.72 & $<0.001$ & $8 \%( \pm 0.34)$ \\
\hline \multirow[t]{4}{*}{ HadGEM2-ES } & 2050 & grouse & $-36 \%( \pm 0.52)$ & 238.07 & $<0.001$ & $64 \%( \pm 0.59)$ \\
\hline & & snowcock & $-91 \%( \pm 0.35)$ & 28.72 & $<0.001$ & $9 \%( \pm 0.35)$ \\
\hline & 2070 & grouse & $-57 \%( \pm 1.94)$ & 639.67 & $<0.001$ & $42 \%( \pm 1.87)$ \\
\hline & & snowcock & $-100 \%( \pm 0.04)$ & 28.65 & $<0.001$ & $0 \%( \pm 0.04)$ \\
\hline \multirow[t]{4}{*}{ INMCM4.0 } & 2050 & grouse & $-23 \%( \pm 0.46)$ & 152.05 & $<0.001$ & $76 \%( \pm 0.41)$ \\
\hline & & snowcock & $-60 \%( \pm 0.70)$ & 28.68 & $<0.001$ & $40 \%( \pm 0.68)$ \\
\hline & 2070 & grouse & $-19 \%( \pm 0.34)$ & 136.20 & $<0.001$ & $79 \%( \pm 0.45)$ \\
\hline & & snowcock & $-45 \%( \pm 0.48)$ & 28.48 & $<0.001$ & $54 \%( \pm 0.42)$ \\
\hline \multirow[t]{4}{*}{ MIROC-ESM } & 2050 & grouse & $-35 \%( \pm 0.67)$ & 262.04 & $<0.001$ & $58 \%( \pm 0.62)$ \\
\hline & & snowcock & $-90 \%( \pm 0.98)$ & 12.85 & $<0.001$ & $10 \%( \pm 0.98)$ \\
\hline & 2070 & grouse & $-67 \%( \pm 0.46)$ & 262.04 & $<0.001$ & $30 \%( \pm 0.42)$ \\
\hline & & snowcock & $-100 \%( \pm 0.00)$ & 28.64 & $<0.001$ & $0 \%( \pm 0.00)$ \\
\hline \multirow[t]{4}{*}{ NorESM1-M } & 2050 & grouse & $-36 \%( \pm 0.48)$ & 210.53 & $<0.001$ & $63 \%( \pm 0.62)$ \\
\hline & & snowcock & $-90 \%( \pm 1.01)$ & 28.79 & $<0.001$ & $10 \%( \pm 1.01)$ \\
\hline & 2070 & grouse & $-36 \%( \pm 1.24)$ & 243.43 & $<0.001$ & $61 \%( \pm 1.43)$ \\
\hline & & snowcock & $-95 \%( \pm 0.67)$ & 28.78 & $<0.001$ & $5 \%( \pm 0.67)$ \\
\hline
\end{tabular}


a.

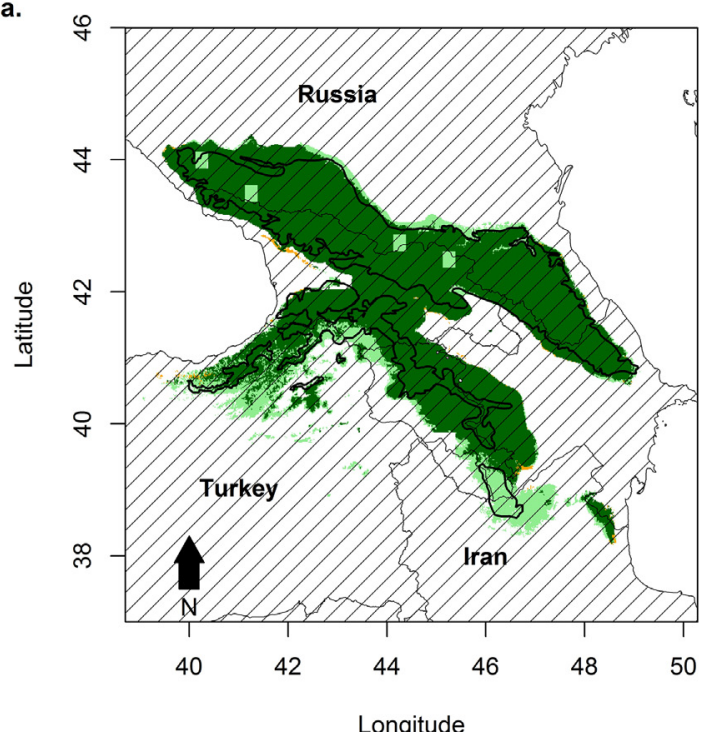

c.

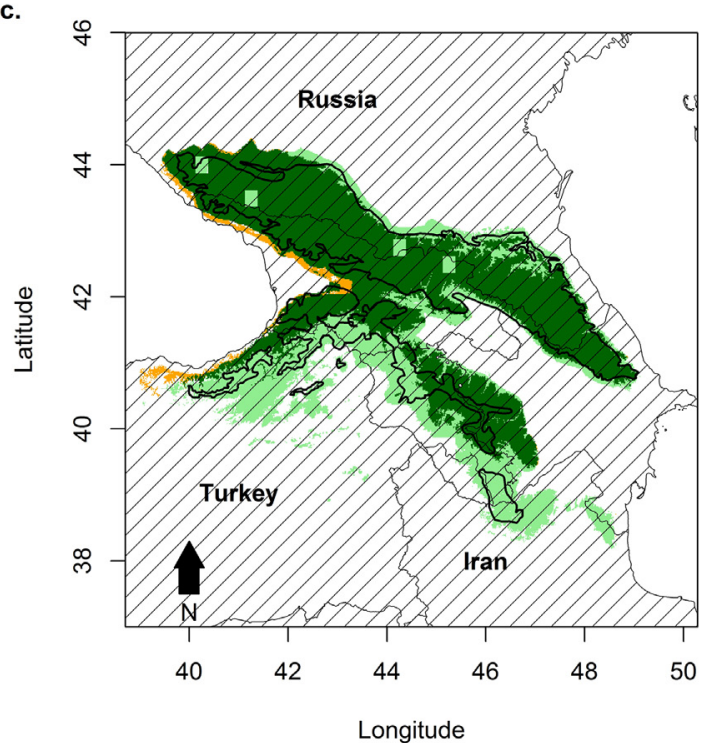

b.

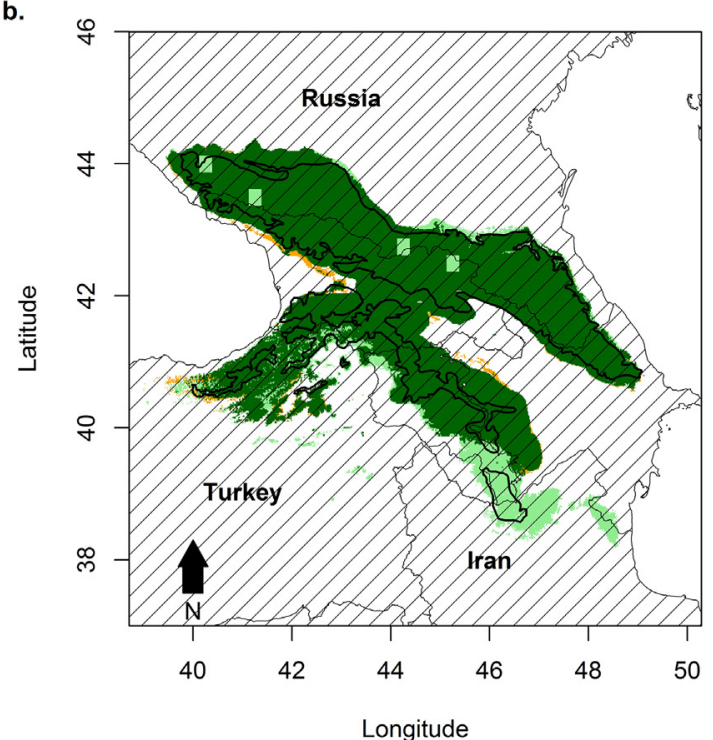

d.

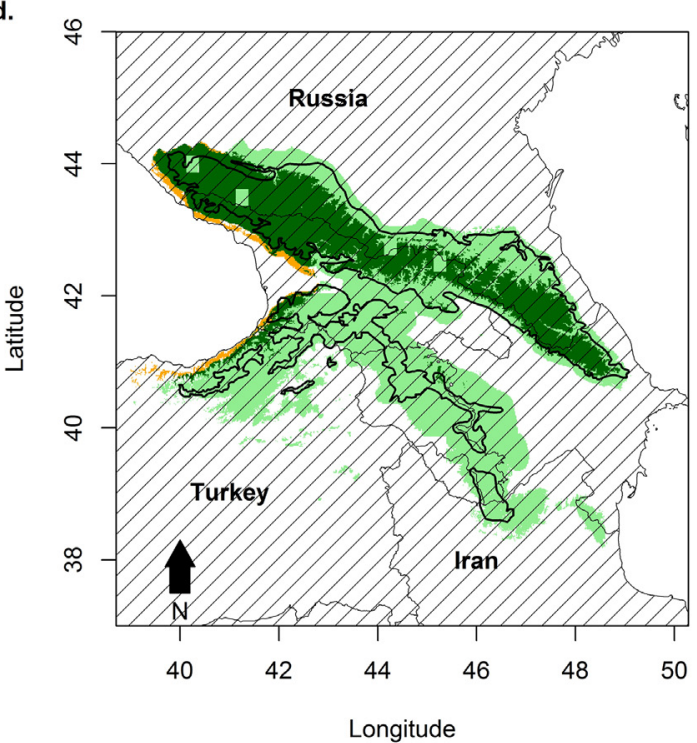

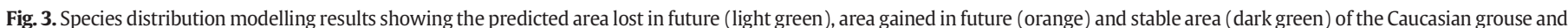

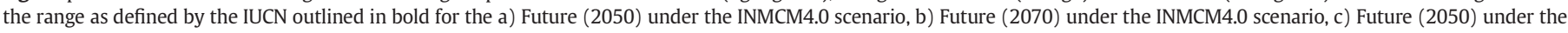

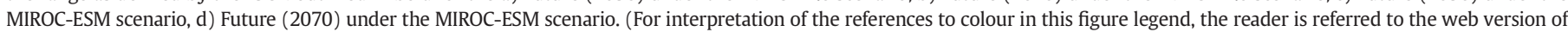
this article.)

Both species received similar scores on the natural history traitindex although information could not be found for some traits (Table 3). Both species scored highly, i.e. at greater risk of extinction, for being ground nesting and habitat specialists (Table 3). In addition, both species have relatively long incubation periods and in general only have a single brood (Table 3 ). In contrast, both species are largely sedentary which scored less in the trait-index. The trait vulnerability scores were 0.55 and 0.60 for the grouse and the snowcock respectively. The combination of the climatic vulnerability score and the trait vulnerability score place both species on the edge of or in the "Most vulnerable" category (Fig. 8).

\section{Discussion}

Our study indicates that both the Caucasian grouse and the Caucasian snowcock are vulnerable to climate change due to the high scores on the exposure-index ( 0.5 for the grouse and 1.0 for the snowcock). The very high score on the exposure-index for the snowcock is because its current potential geographic distribution range is predicted to decrease with on average $86 \%$, and only on average $14 \%$ of its current predicted range remains suitable in future. It is predicted by two of the five climate change scenarios used in this study, the HadGEM2-ES and the MIROC-ESM, that there is no suitable area left by 2070 for the snowcock. The geographic distribution range loss was predicted to be less severe for the grouse $(-44 \%)$, whilst a larger proportion of the range was predicted to remain stable (53\%). Surprisingly, according to the INMCM4.0 scenario, the loss was greater in the year 2050 than in the year 2070 for both the grouse and the snowcock. Reasons for this are unclear. Changing temperature and precipitation regimes appeared to be the most important cause of this loss in geographic range. Predictor variables related to changes in land use did not appear in the top predictor variables for neither the grouse nor the snowcock and hence a changing climate, rather than associated changes in land-use, appear to be the principal drivers of future range shifts for both species.

In addition, both species have several natural history traits that may make them even more vulnerable to future climate change. They for 
a.

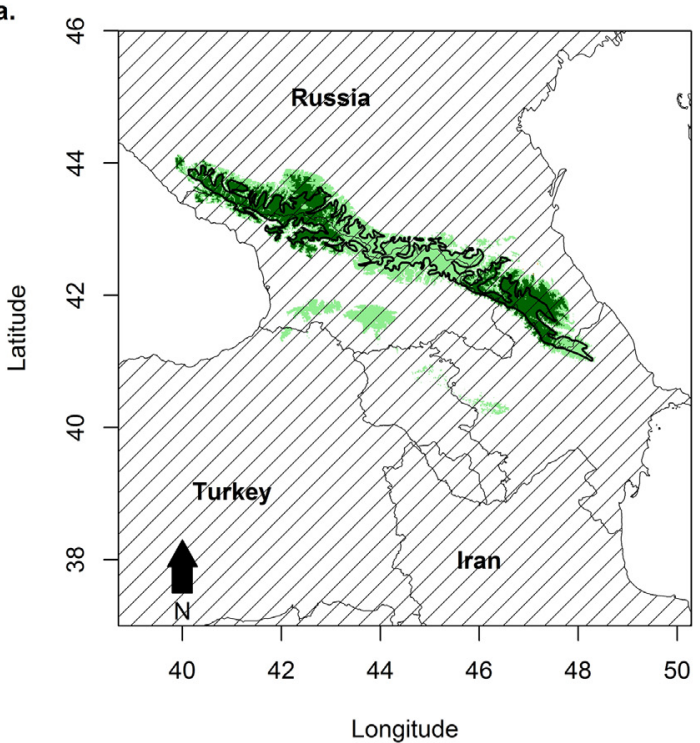

c.

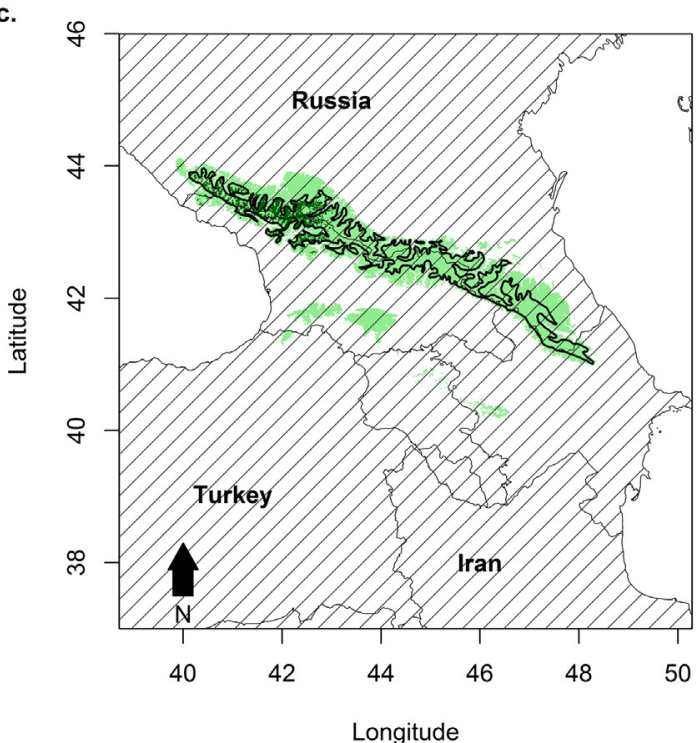

b.

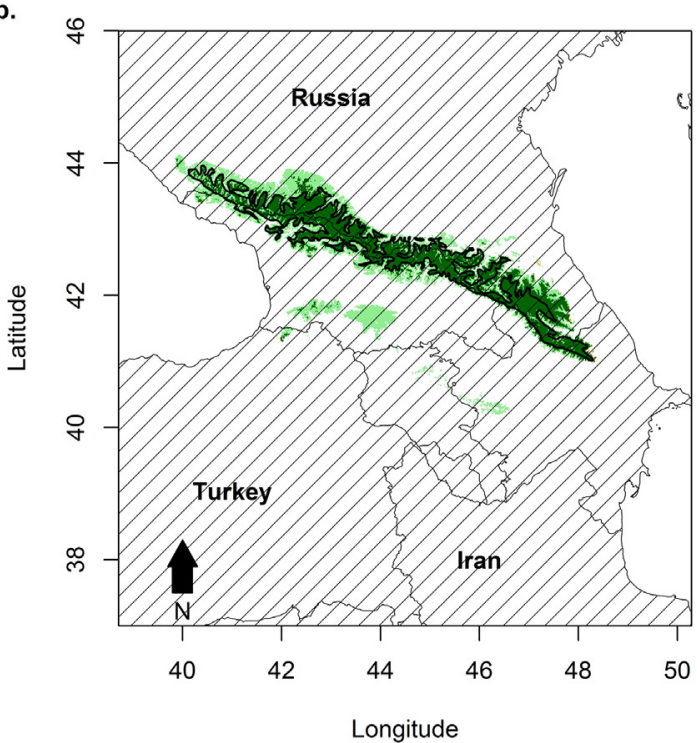

d.

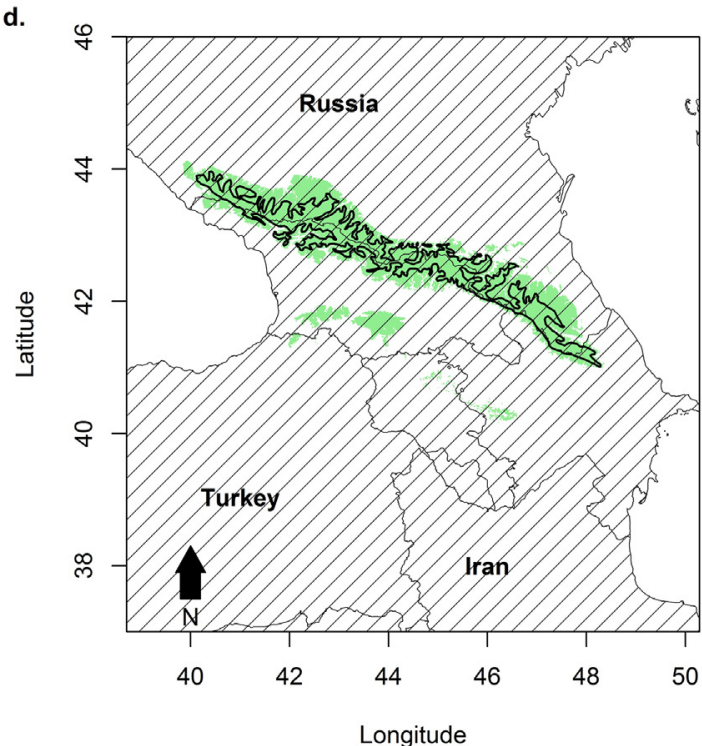

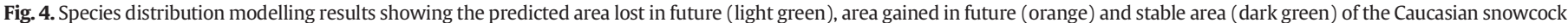

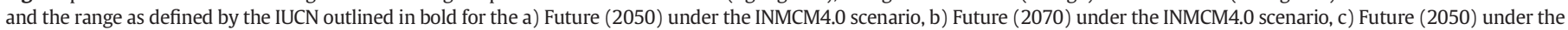

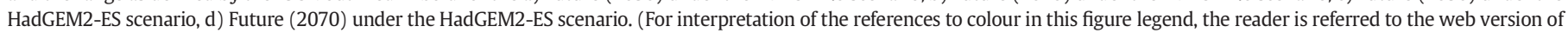
this article.)

instance both exhibit ground nesting behaviour that may lead to increased predation pressure from potentially expanding distribution ranges of mammalian and avian predators. Unfortunately, it is not known if, and to what extent, predators of eggs and chicks are going to be more abundant in the region in future or not. Both species also have a relatively poor reproductive capacity based on the length of the breeding season, and their reproductive capacity. These characteristics mean that they scored 0.55 and 0.60 respectively on the traits-index. Combining the exposure-index and the traits-index places the snowcock firmly in the "Most vulnerable" category of the vulnerability matrix developed by Hof et al. (2017) whilst the grouse was on the border between the "Most vulnerable" and the "Trait vulnerable" categories.

A further factor that may make the species even more vulnerable than shown by the vulnerability matrix is that our study predicted that the current geographic distributions of both the grouse and the snowcock should be larger than the distribution range currently defined by the IUCN. This signifies that there are other factors not considered in this study that limit their distribution. This is not unexpected since the grouse is currently already assessed as Near Threatened on the IUCN red list of threatened species, which is likely due to hunting, overgrazing, wood cutting, and habitat fragmentation (Gokhelashvili et al., 2003; BirdLife International, 2016). Such factors often cannot be considered in species distribution modelling algorithms but may also limit the current distribution range of species and further limit the predicted future ranges that we estimate in this study. The fact that our models only performed fair, based on the AUC score, may further confirm that certain important factors driving the distribution of both species are lacking in the models. That the analyses took place at a 30 arc sec scale, the finest spatial scale currently available for future climate scenario data provided by WorldClim, may also be a reason for the fair performance.

Changing climatic conditions may have further indirect effects on species as well (Bentz et al., 2010, Blaustein et al., 2010). Precipitation falling as rain or snow in the higher elevations could have direct consequences on the habitats which both the snowcock and grouse rely upon. 

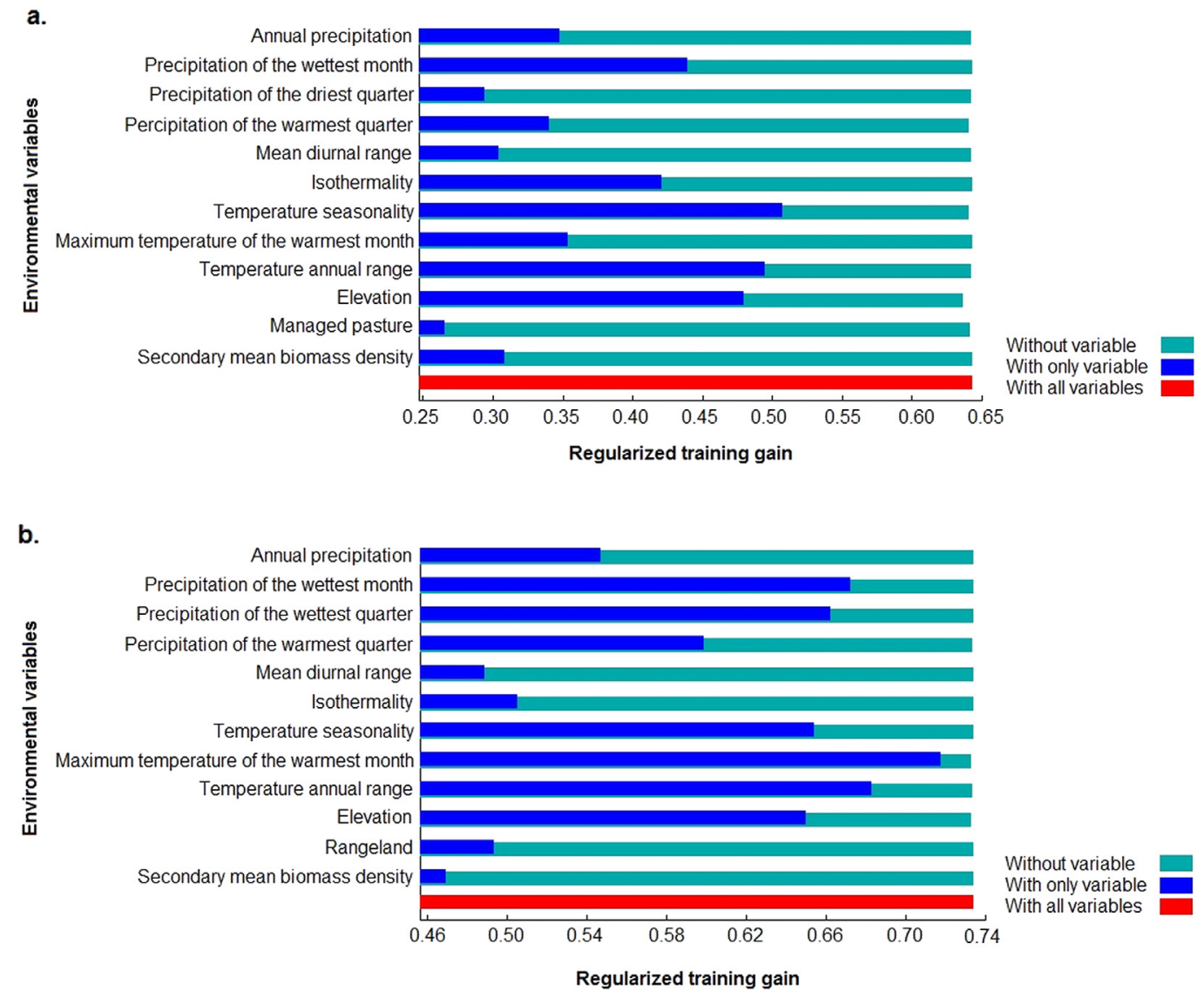

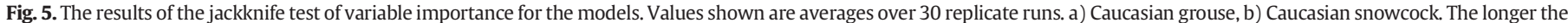
blue bar, the more important the predictor variable. (For interpretation of the references to colour in this figure legend, the reader is referred to the web version of this article.)

High-latitude and altitude areas are characterized by a period of high primary productivity in spring that is coupled with the melting snow and warmer temperatures (Billings and Bliss, 1959). This period of growth provides an important food source, especially for herbivores which feed upon the new shoots of plants, like the grouse and the snowcock (Cramp et al., 1979). Hence, not only may the future climatic suitability reduce, but additional feedback mechanisms may affect the species due to how the future changing climate also affects vegetation dynamics. The snowcock appeared to be strongly affected by

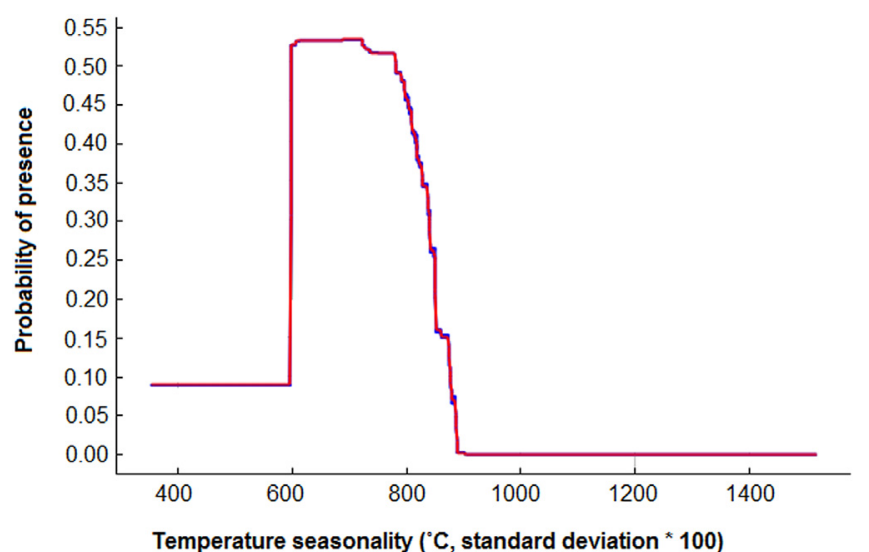

Fig. 6. The contribution of the predictor variable 'Temperature seasonality' to model predictive power of the Caucasian grouse. temperature, with a sudden decline in suitability when the warmest month was above $22^{\circ} \mathrm{C}$ (Fig. 7) which may be related to local vegetation dynamics, for example how temperature governs the altitude of the treeline and associated biotopes which will likely change in a future warmer climate (Körner and Paulsen, 2004; Nakhutsrishvili et al., 2006). The lower levels of precipitation, and reduced seasonality, may also result in behavioural changes such as the loss of altitudinal migrations performed by both species. Species that exhibit altitudinal migration behaviours likely do not face the same challenges as long-distance

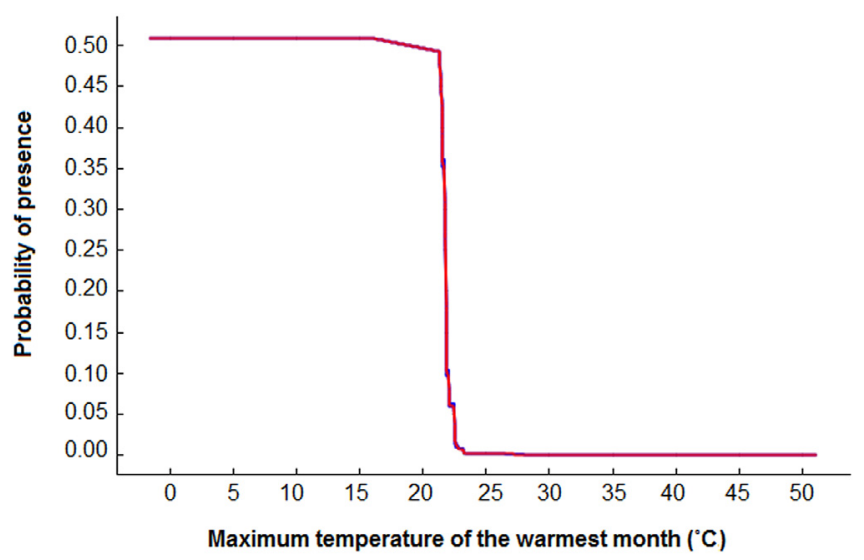

Fig. 7. The contribution of the predictor variable 'Maximum temperature of the warmest month' to model predictive power of the Caucasian snowcock. 
Table 3

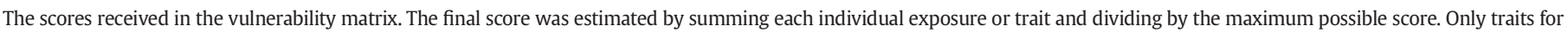
which information could be found were included when estimating the final score.

\begin{tabular}{|c|c|c|c|c|c|}
\hline Index & Characteristic/trait & Grouse & Score & Snowcock & Score \\
\hline \multirow[t]{2}{*}{ Exposure } & Percentage gain in range size in 2070 compared to current & $-44 \%( \pm 7)$ & 2 & $-86 \%( \pm 21)$ & 2 \\
\hline & Percentage stable area in 2070 & $53 \%( \pm 16)$ & 0 & $14 \%( \pm 21)$ & 2 \\
\hline Score & & & 0.50 & & 1.00 \\
\hline \multirow[t]{12}{*}{ Traits } & Migrating & Sedentary & 0 & Sedentary & 0 \\
\hline & Diet breath & No preferred food item & 0 & No preferred food item & 0 \\
\hline & Habitat specialist & Largely dependent on a singular biome & 2 & Largely dependent on a singular biome & 2 \\
\hline & Ground nesting & Yes & 2 & Yes & 2 \\
\hline & Average clutch size & $2-13$ eggs (mean 6 ) & 1 & 5-8 eggs (mean 6) & 1 \\
\hline & $\mathrm{N}$ incubation days & $20-25$ days & 1 & 28 days & 2 \\
\hline & $\mathrm{N}$ fledging days & $28-35$ days & 1 & 28 days & 1 \\
\hline & Length breeding season & 2 to 3 months & 1 & 2 to 3 months & 1 \\
\hline & $\mathrm{N}$ broods & 1 brood & 2 & 1 brood & 2 \\
\hline & Adult survival rates & NA & NA & NA & NA \\
\hline & Age at first breeding & $1-2$ & 1 & $1-2$ & 1 \\
\hline & Maximum lifespan & NA & NA & NA & NA \\
\hline Score & & & 0.55 & & 0.60 \\
\hline
\end{tabular}

migrants (Jenni and Kery, 2003), however it is uncertain how yearround browsing pressure may impact plant communities at high elevations.

A potential decline of both the snowcock and the grouse may have more far reaching effects on other species as well as on local communities. First, negative impacts of climate change on prey species may have further consequences higher up the food chain. A species like the snowcock is also an important prey item for several species that are already listed on the IUCN red list of threatened species such as the leopard (Panthera pardus) (Mallon et al., 2007) and the bearded vulture (Gypaetus barbatus) (Gavashelishvili and McGrady, 2006; http://zverevedia.ru/katalog/k/ kavkazskii_ular), and also for species like the Caucasian lynx (Lynx lynx dinniki) (Baziev, 1978) in http://www.egir.ru/bird/38.html), and the golden eagle (Aquila chrysaetos). Second, the snowcock has a high aesthetic value in the region since it is said to be a symbol of incredible heights (http://www.egir.ru/bird/38.html) and is also unique to this

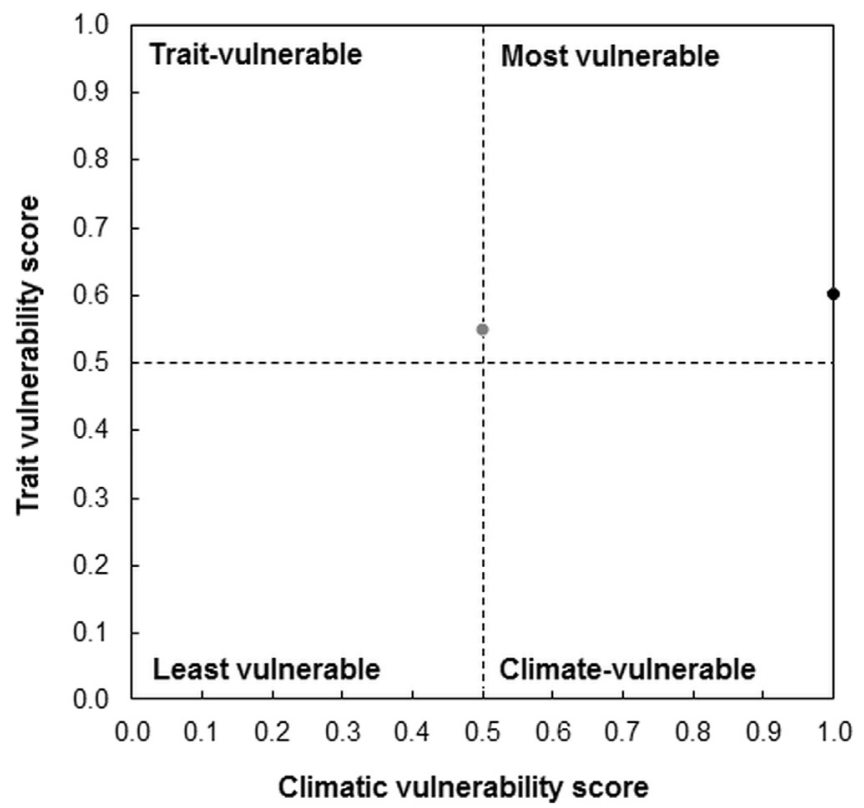

- Caucasian grouse - Caucasian snowcock

Fig. 8. Vulnerability matrix (adapted from Hof et al., 2017) showing the exposure- and trait-based indices for the Caucasian grouse and the Caucasian snowcock. Both species are in the "Most Vulnerable" category given that both indices score $\geq 0.5$. region being one of the few endemic bird species of Europe. Third, the species is favoured by hunters (http://www.hunt-dogs.ru/kavkazskii ular/, http://zverevedia.ru/katalog/k/kavkazskii_ular). The hunting on grouse is however sporadic and not seen as a large threat (Gokhelashvili et al., 2003) but would need careful monitoring to ensure that it does not expose the species to threats in the face of climate change.

\section{Conclusion}

Our study indicates that especially the Caucasian snowcock and to a lesser extent the Caucasian grouse are highly vulnerable to future climate change due to a large decline of suitable areas in future. Both species also exhibit several traits, like habitat specialism, that may increase these risks. Worryingly, there appears to be few ongoing research projects, for example little is known about the survival rates of both species and also longevity. Current population estimates show wide confidence intervals (Gokhelashvili et al., 2003; BirdLife International, 2016, 2017) and research projects are urgently needed in this region to improve our understanding of the full magnitude of threats facing these species in future. Given the endemism of both the grouse and the snowcock, and the limited ability to disperse to new areas or expand their ranges to higher elevations, careful monitoring actions are needed to determine how the grouse and snowcock respond to future climate change, and to potentially begin implementing management actions like habitat improvements, controlling grazing pressure and implementing hunting quotas. An additional challenge, both in conserving the species and managing hunting, is that the range of both the grouse and the snowcock is on the frontier of several countries and hence requires transboundary collaborative conservation actions to ensure the future preservation of the species (Zbicz, 2003).

\section{Acknowledgment}

We would like to thank two anonymous reviewers for valuable comments that improved the paper.

\section{References}

ACIA, 2004. Impacts of a Warming Arctic - Arctic Climate Impact Assessment. Cambridge University Press, Cambridge, p. 139.

Anderson, R.P., Raza, A. 2010. The effect of the extent of the study region on GIS models of species geographic distributions and estimates of niche evolution: preliminary tests with montane rodents (genus Nephelomys) in Venezuela. J. Biogeogr. 37, 1378-1393. https://doi.org/10.1111/j.1365-2699.2010.02290.x.

Araújo, M.B., Luoto, M., 2007. The importance of biotic interactions for modelling species distributions under climate change. Glob. Ecol. Biogeogr. 16, 743-753. https://doi.org/ 10.1111/j.1466-8238.2007.00359.x

Baziev, D.H., 1978. The Snowcocks of the Caucasus. Nauka (Science), St Petersburg. 
Bentsen, M., Bethke, I., Debernard, J.B., Iversen, T., Kirkevåg, A., Seland, Ø., Drange, H. Roelandt, C., Seierstad, I.A., Hoose, C., Kristjánsson, J.E., 2013. The Norwegian Earth System Model, NorESM1-M - Part 1: description and basic evaluation of the physical climate. Geosci. Model Dev. 6, 687-720. https://doi.org/10.5194/gmd-6-687-2013.

Bentz, B.J., Regniere, J., Fettig, C.J., Hansen, E.M., Hayes, J.L., Hicke, J.A., Kelsey, R.G., Negron, J.F., Seybold, S.J., 2010. Climate change and bark beetles of the western United States and Canada: direct and indirect effects. BioScience 60 (8), 602-613.

Billings, W.D., Bliss, L.C., 1959. An alpine snowbank environment and its effects on vegetation, plant development, and productivity. Ecology 40, 388-397. https://doi.org/ $10.2307 / 1929755$.

BirdLife International, 2016. Lyrurus mlokosiewiczi. IUCN Red List Threat Species 2016:e. T22679483A92815595.

BirdLife International, 2017. Tetraogallus caucasicus. IUCN Red List Threat Species 2017:e. T22678661A111767442.

Blaustein, A.R., Walls, S.C., Bancroft, B.A., Lawler, J.J., Searle, C.L., Gervasi, S.S., 2010. Direct and indirect effects of climate change on amphibian populations. Diversity 2, 281-313. https://doi.org/10.3390/d2020281.

Braunisch, V., Suchant, R., 2008. Using ecological forest site mapping for long-term habitat suitability assessments in wildlife conservation-demonstrated for capercaillie (Tetrao urogallus). For. Ecol. Manag. 256, 1209-1221. https://doi.org/10.1016/J. FORECO.2008.06.027.

Cramp, S., Simmons, K.E.L., Gillmor, R., Hollom, P.A.D., Hudson, R., Nicholson, E.M., Ogilvie, M.A., Olney, P.J.S., Roselaar, C.S., Voous, K.H., Wallace, D.I.M., Wattel, J., 1979. The birds of the western Palearctic. Hawks to Bustards. Vol. 2. Oxford University Press, Oxford, UK.

Deutsch, C.A., Tewksbury, J.J., Huey, R.B., Sheldon, K.S., Ghalambor, C.K., Haak, D.C., Martin, P.R., 2008. Impacts of climate warming on terrestrial ectotherms across latitude. Proc. Natl. Acad. Sci. 105, 6668-6672. https://doi.org/10.1073/pnas.0709472105.

Elith, J., Graham, C., Anderson, R., Dudik, M., Ferrier, S., Guisan, A., Hijmans, R., Huettmann, F., Leathwick, J., Lehmann, A., Li, J., Lohmann, L., Loiselle, B., Manion, G., Moritz, C., Nakamura, M., Nakazawa, Y., Overton, J., Peterson, A., Phillips, S., Richardson, K., Scachetti-Pereira, R., Schapire, R., Soberon, J., Williams, S., Wisz, M., Zimmermann, N., 2006. Novel methods improve prediction of species' distributions from occurrence data. Ecography (Сop.). 29, 129-151. https://doi.org/10.1111/j.2006.09067590.04596.x.

Elith, J., Phillips, S.J., Hastie, T., Dudík, M., Chee, Y.E., Yates, C.J., 2011. A statistical explanation of MaxEnt for ecologists. Divers. Distrib. 17, 43-57. https://doi.org/10.1111/ j.1472-4642.2010.00725.x.

Engler, R., Randin, C.F., Thuiller, W., Dullinger, S., Zimmermann, N.E., Araújo, M.B. Pearman, P.B., Le Lay, G., Piedallu, C., Albert, C.H., Choler, P., Coldea, G., De Lamo, X., Dirnböck, T., Gégout, J.-C., Gómez-García, D., Grytnes, J.-A., Heegaard, E., Høistad, F., Nogués-Bravo, D., Normand, S., Pușcaş, M., Sebastià, M.-T., Stanisci, A., Theurillat, J.P., Trivedi, M.R., Vittoz, P., Guisan, A., 2011. 21st century climate change threatens mountain flora unequally across Europe. Glob. Chang. Biol. 17, 2330-2341. https:// doi.org/10.1111/j.1365-2486.2010.02393.x.

Eyring, V., Bony, S., Meehl, G.A., Senior, C.A., Stevens, B., Stouffer, R.J., Taylor, K.E., 2016 Overview of the coupled model Intercomparison project phase 6 (CMIP6) experimental design and organization. Geosci. Model Dev. 9, 1937-1958. https://doi.org/ 10.5194/gmd-9-1937-2016.

Foden, W.B., Butchart, S.H.M., Stuart, S.N., Vié, J.-C., Akçakaya, H.R., Angulo, A., Devantier, L.M., Gutsche, A., Turak, E., Cao, L., Donner, S.D., Katariya, V., Bernard, R., Holland, R.A., Hughes, A.F., O'Hanlon, S.E., Garnett, S.T., Şekercioğlu, Ç.H., Mace, G.M., 2013. Identifying the world's most climate change vulnerable species: a systematic trait-based assessment of all birds, amphibians and corals. PLoS One 8, e65427. https://doi.org/ 10.1371/journal.pone.0065427.

Fu, C., Hua, X., Li, J., Chang, Z., Pu, Z., Chen, J., 2006. Elevational patterns of frog species richness and endemic richness in the Hengduan Mountains, China: geometric constraints, area and climate effects. Ecography (Cop.). 29, 919-927. https://doi.org/ 10.1111/j.2006.0906-7590.04802.x.

Gavashelishvili, A., Javakhishvili, Z., 2010. Combining radio-telemetry and random observations to model the habitat of Near Threatened Caucasian grouse Tetrao mlokosiewiczi. Oryx 44, 491-500. https://doi.org/10.1017/S0030605310000979.

Gavashelishvili, A., McGrady, M.J., 2006. Breeding site selection by bearded vulture (Gypaetus barbatus) and Eurasian griffon (Gyps fulvus) in the Caucasus. Anim. Conserv. 9, 159-170. https://doi.org/10.1111/j.1469-1795.2005.00017.x.

Gokhelashvili, R., Kerry, P.R., Gavashelishvili, L., 2003. How much do we know about the Caucasian Black Grouse Tetrao mlokosiewiczi. Sandgrouse 25, 33-40.

Gottschalk, T.K., Ekschmitt, K., İsfendiyaroglu, S., Gem, E., Wolters, V., 2007. Assessing the potential distribution of the Caucasian black grouse Tetrao mlokosiewiczi in Turkey through spatial modelling. J. Ornithol. 148, 427-434. https://doi.org/10.1007/ s10336-007-0155-z.

Habibzadeh, N., Karami, M., Alavipanah, S.K., Riazi, B., 2013. Landscape requirements of Caucasian Grouse (Lyrurus mlokosiewiczi) in Arasbaran region, East Azerbaijan, Iran. Wilson J. Ornithol. 125, 140-149. https://doi.org/10.1676/09-169.1.

Hijmans, R.J., Graham, C.H., 2006. The ability of climate envelope models to predict the effect of climate change on species distributions. Glob. Chang. Biol. 12, 2272-2281. https://doi.org/10.1111/j.1365-2486.2006.01256.x.

Hijmans, R.J., Cameron, S.E., Parra, J.L., Jones, P.G., Jarvis, A., 2005. Very high resolution interpolated climate surfaces for global land areas. Int. J. Climatol. 25, 1965-1978. https://doi.org/10.1002/joc.1276.

Hijmans, R.J., Phillips, S., Leathwick, J., Elith, J., 2017. dismo: Species Distribution Modeling.

Hof, A.R., 2015. Alien species in a warming climate: a case study of the nutcracker and stone pines. Biol. Invasions 17, 1533-1543. https://doi.org/10.1007/s10530-0140813-Z.

Hof, A.R., Jansson, R., Nilsson, C., 2012a. How biotic interactions may alter future predictions of species distributions: future threats to the persistence of the arctic fox in Fennoscandia. Divers. Distrib. 18, 554-562. https://doi.org/10.1111/ j.1472-4642.2011.00876.x.

Hof, A.R., Jansson, R., Nilsson, C., 2012b. The usefulness of elevation as a predictor variable in species distribution modelling. Ecol. Model. 246, 86-90. https://doi.org/10.1016/J. ECOLMODEL.2012.07.028.

Hof, A.R., Rodríguez-Castañeda, G., Allen, A.M., Jansson, R., Nilsson, C., 2017. Vulnerability of subarctic and Arctic breeding birds. Ecol. Appl. 27. https://doi.org/10.1002/ eap.1434.

Huntingford, C., Mercado, L.M., 2016. High chance that current atmospheric greenhouse concentrations commit to warmings greater than $1.5{ }^{\circ} \mathrm{C}$ over land. Sci. Rep. 6 , 30294. https://doi.org/10.1038/srep30294.

Hurtt, G.C., Chini, L.P., Frolking, S., Betts, R.A., Feddema, J., Fischer, G., Fisk, J.P., Hibbard, K., Houghton, R.A., Janetos, A., Jones, C.D., Kindermann, G., Kinoshita, T., Klein Goldewijk, K., Riahi, K., Shevliakova, E., Smith, S., Stehfest, E., Thomson, A., Thornton, P., van Vuuren, D.P., Wang, Y.P., 2011. Harmonization of land-use scenarios for the period 1500-2100: 600 years of global gridded annual land-use transitions, wood harvest, and resulting secondary lands. Clim. Chang. 109, 117-161. https://doi.org/10.1007/ s10584-011-0153-2.

IPCC, 2013. IPCC Fifth Assessment Report (AR5) - The Physical Science Basis.

Jenni, L., Kery, M., 2003. Timing of autumn bird migration under climate change: advances in long-distance migrants, delays in short-distance migrants. Proc. R. Soc. B Biol. Sci. 270, 1467-1471. https://doi.org/10.1098/rspb.2003.2394

Jones, C., Hughes, J.K., Bellouin, N., Hardiman, S.C., Jones, G.S., Knight, J., Liddicoat, S., O'Connor, F.M., Andres, R.J., Bell, C., Boo, K.O., Bozzo, A., Butchart, N., Cadule, P., Corbin, K.D., Doutriaux-Boucher, M., Friedlingstein, P., Gornall, J., Gray, L., Halloran, P.R., Hurtt, G., Ingram, W.J., Lamarque, J.-F., Law, R.M., Meinshausen, M., Osprey, S., Palin, E.J., Parsons Chini, L., Raddatz, T., Sanderson, M.G., Sellar, A.A., Schurer, A. Valdes, P., Wood, N., Woodward, S., Yoshioka, M., Zerroukat, M., 2011. The HadGEM2-ES implementation of CMIP5 centennial simulations. Geosci. Model Dev. 4, 543-570. https://doi.org/10.5194/gmd-4-543-2011.

Kessler, M., 2002. The elevational gradient of Andean plant endemism: varying influences of taxon-specific traits and topography at different taxonomic levels. J. Biogeogr. 29, 1159-1165. https://doi.org/10.1046/j.1365-2699.2002.00773.x.

Klein Goldewijk, K., Beusen, A., Doelman, J., Stehfest, E., 2017. Anthropogenic land use estimates for the Holocene - HYDE 3.2. Earth Syst. Sci. Data 9, 927-953. https://doi.org/ 10.5194/essd-9-927-2017.

Körner, C., Paulsen, J., 2004. A world-wide study of high altitude treeline temperatures J. Biogeogr. 31, 713-732. https://doi.org/10.1111/j.1365-2699.2003.01043.x.

Liu, C., Berry, P.M., Dawson, T.P., Pearson, R.G., 2005. Selecting thresholds of occurrence in the prediction of species distributions. Ecography (Cop.) 28, 385-393. https://doi.org/ 10.1111/j.0906-7590.2005.03957.x.

Malcolm, J.R., Liu, C., Neilson, R.P., Hansen, L., Hannah, L., 2006. Global warming and extinctions of endemic species from biodiversity hotspots. Conserv. Biol. 20, 538-548.

Mallon, D., Weinberg, P., Kopaliani, N., 2007. Status of the prey species of the leopard in the Caucasus. Cat News Special Issue 2, 22-27.

McGowan, P.J.K., Kirwan, G.M., Boesman, P., 2018. Caucasian Snowcock (Tetraogallus caucasicus). In: del Hoyo, J., Elliott, A., Sargatal, J., Christie, D.A., de Juana, E. (Eds.), Handbook of the Birds of the World Alive. Lynx Edicions, Barcelona.

Merow, C., Smith, M.J., Silander, J.A., Merow, C., Silander, J.A., 2013. A Practical Guide to MaxEnt for Modeling Species' Distributions: What It Does, and Why Inputs and Settings Matter. https://doi.org/10.1111/j.1600-0587.2013.07872.x.

Murray, H., Green, E., Williams, D., Burfield, I., Brooke M De, L., 2015. Is research effort associated with the conservation status of European bird species? Endanger. Species Res. 27, 193-206. https://doi.org/10.3354/esr00656.

Nakhutsrishvili, G., Abdaladze, O., Akhalkatsi, M., 2006. Biotope types of the treeline of the Central Greater Caucasus. Nature Conservation. Springer, Berlin, Heidelberg pp. 211-225 https://doi.org/10.1007/978-3-540-47229-2_22.

Nogués-Bravo, D., Araújo, M.B., Errea, M.P., Martínez-Rica, J.P., 2007. Exposure of global mountain systems to climate warming during the 21st century. Glob. Environ. Chang. 17, 420-428. https://doi.org/10.1016/J.GLOENVCHA.2006.11.007.

O'Neill, B.C., Tebaldi, C., van Vuuren, D.P., Eyring, V., Friedlingstein, P., Hurtt, G., Knutti, R., Kriegler, E., Lamarque, J.-F., Lowe, J., Meehl, G.A., Moss, R., Riahi, K., Sanderson, B.M., 2016. The scenario model intercomparison project (ScenarioMIP) for CMIP6. Geosci. Model Dev. 9, 3461-3482. https://doi.org/10.5194/gmd-9-3461-2016.

Orme, C.D.L., Davies, R.G., Burgess, M., Eigenbrod, F., Pickup, N., Olson, V.A., Webster, A.J., Ding, T.-S., Rasmussen, P.C., Ridgely, R.S., Stattersfield, A.J., Bennett, P.M., Blackburn, T.M., Gaston, K.J., Owens, I.P.F., 2005. Global hotspots of species richness are not congruent with endemism or threat. Nature 436, 1016-1019. https://doi.org/10.1038/ nature03850.

Parmesan, C., Ryrholm, N., Stefanescu, C., Hill, J.K., Thomas, C.D., Descimon, H., Huntley, B. Kaila, L., Kullberg, J., Tammaru, T., Tennent, W.J., Thomas, J.A., Warren, M., 1999. Poleward shifts in geographical ranges of butterfly species associated with regional warming. Nature 399, 579-583. https://doi.org/10.1038/21181.

Patthey, P., Wirthner, S., Signorell, N., Arlettaz, R., 2008. Impact of outdoor winter sports on the abundance of a key indicator species of alpine ecosystems. J. Appl. Ecol. 45, 1704-1711. https://doi.org/10.1111/j.1365-2664.2008.01547.x.

Peterson, A.J., Soberón, J., Pearson, R.G., Anderson, R.P., Martínez-Meyer, E., Nakamura, M.B.A., 2011. Ecological Niches and Geographic Distributions (MPB-49). Princeton University Press, Princeton, U.S.A.

Phillips, S.J., Dudík, M., 2008. Modeling of species distributions with Maxent: new extensions and a comprehensive evaluation. Ecography (Cop.) 31, 161-175. https://doi. org/10.1111/j.0906-7590.2008.5203.X.

Phillips, S.J., Anderson, R.P., Schapire, R.E., 2006. Maximum entropy modeling of species geographic distributions. Ecol. Model. 190, 231-259. https://doi.org/10.1016/J ECOLMODEL.2005.03.026. 
Pounds, J.A., Fogden, M.P.L., Campbell, J.H., 1999. Biological response to climate change on a tropical mountain. Nature 398, 611-615. https://doi.org/10.1038/19297.

R Development Core Team, 2016. R: A Language and Environment for Statistical Computing. R Foundation for Statistical Computing, Vienna, Austria URL. https://www.R-project.org.

Radosavljevic, A., Anderson, R.P., 2014. Making better M axent models of species distributions: complexity, overfitting and evaluation. J. Biogeogr. 41, 629-643. https://doi. org/10.1111/jbi.12227.

Riahi, K., Rao, S., Krey, V., Cho, C., Chirkov, V., Fischer, G., Kindermann, G., Nakicenovic, N., Rafaj, P., 2011. RCP 8.5-a scenario of comparatively high greenhouse gas emissions. Clim. Chang. 109, 33-57. https://doi.org/10.1007/s10584-011-0149-y.

Riahi, K., van Vuuren, D.P., Kriegler, E., Edmonds, J., O'Neill, B.C., Fujimori, S., Bauer, N., Calvin, K., Dellink, R., Fricko, O., Lutz, W., Popp, A., Cuaresma, J.C., Kc, S., Leimbach, M., Jiang, L., Kram, T., Rao, S., Emmerling, J., Ebi, K., Hasegawa, T., Havlik, P., Humpenöder, F., Da Silva, L.A., Smith, S., Stehfest, E., Bosetti, V., Eom, J., Gernaat, D., Masui, T., Rogelj, J., Strefler, J., Drouet, L., Krey, V., Luderer, G., Harmsen, M., Takahashi, K., Baumstark, L., Doelman, J.C., Kainuma, M., Klimont, Z., Marangoni, G. Lotze-Campen, H., Obersteiner, M., Tabeau, A., Tavoni, M., 2017. The shared socioeconomic pathways and their energy, land use, and greenhouse gas emissions implications: an overview. Glob. Environ. Chang. 42, 153-168. https://doi.org/10.1016/J. GLOENVCHA.2016.05.009.

Roberge, J.-M., Angelstam, P., 2004. Usefulness of the umbrella species concept as a conservation tool. Conserv. Biol. 18, 76-85. https://doi.org/10.1111/j.15231739.2004.00450.x.

Rodríguez-Castañeda, G., Hof, A.R., Jansson, R., Harding, L.E., 2012. Predicting the fate of biodiversity using species' distribution models: enhancing model comparability and repeatability. PLoS One 7, e44402. https://doi.org/10.1371/journal.pone.0044402.

Sala, O.E., Chapin, F.S., Armesto, J.J., Berlow, E., Bloomfield, J., Dirzo, R., Huber-Sanwald, E., Huenneke, L.F., Jackson, R.B., Kinzig, A., Leemans, R., Lodge, D.M., Mooney, H.A Oesterheld, Martín, Poff, N.L., Sykes, M.T., Walker, B.H., Walker, M., Wall, D.H., 2000 Global biodiversity scenarios for the year 2100. Science 287, 1770-1774. https:// doi.org/10.1126/science.287.5459.1770.

Thomas, C.D., Thomas, C.D., Cameron, A., Cameron, A., Green, R.E., Green, R.E., Bakkenes, M., Bakkenes, M., Beaumont, L.J., Beaumont, L.J., Collingham, Y.C., Collingham, Y.C. Erasmus, B.F.N., Erasmus, B.F.N., De Siqueira, M.F., De Siqueira, M.F., Grainger, A Grainger, A., Hannah, L., Hannah, L., Hughes, L., Hughes, L., Huntley, B., Huntley, B. Van Jaarsveld, A.S., Van Jaarsveld, A.S., Midgley, G.F., Midgley, G.F., Miles, L., Miles, L., Ortega-Huerta, M. a, Ortega-Huerta, M. a, Peterson, A.T., Peterson, A.T., Phillips, O.L., Phillips, O.L., Williams, S.E., Williams, S.E., 2004. Extinction risk from climate change. Nature 427, 145-148. https://doi.org/10.1038/nature02121.
Thuiller, W., Brotons, L., Araújo, M.B., Lavorel, S., 2004. Effects of restricting environmental range of data to project current and future species distributions. Ecography (Сop.) 27, 165-172. https://doi.org/10.1111/j.0906-7590.2004.03673.x.

Thuiller, W., Midgley, G.F., Hughes, G.O., Bomhard, B., Drew, G., Rutherford, M.C., Woodward, F.I., 2006. Endemic species and ecosystem sensitivity to climate change in Namibia. Glob. Chang. Biol. 12, 759-776. https://doi.org/10.1111/j.13652486.2006.01140.x.

Urban, M.C., 2015. Climate change. Accelerating extinction risk from climate change. Science 348, 571-573. https://doi.org/10.1126/science.aaa4984.

Vetaas, O.R., Grytnes, J.-A., 2002. Distribution of vascular plant species richness and endemic richness along the Himalayan elevation gradient in Nepal. Glob. Ecol. Biogeogr. 11, 291-301. https://doi.org/10.1046/j.1466-822X.2002.00297.x.

Volodin, E.M., Dianskii, N.A., Gusev, A.V., 2010. Simulating present-day climate with the INMCM4.0 coupled model of the atmospheric and oceanic general circulations. Izv. Atmos. Ocean. Phys. 46, 414-431. https://doi.org/10.1134/S000143381004002X.

Walther, G.-R., Post, E., Convey, P., Menzel, A., Parmesan, C., Beebee, T.J.C., Fromentin, J.-M., Hoegh-Guldberg, O., Bairlein, F., 2002. Ecological responses to recent climate change. Nature 416, 389-395. https://doi.org/10.1038/416389a.

Watanabe, S., Hajima, T., Sudo, K., Watanabe, S., Hajima, T., Sudo, K., Nagashima, T., Takemura, T., Okajima, H., Nozawa, T., Kawase, H., Abe, M., Yokohata, T., Ise, T., Sato, H., Kato, E., Takata, K., Emori, S., Kawamiya, M., 2011. MIROC-ESM: model description and basic results of CMIP5-20c3m experiments. Geosci. Model Dev. Discuss. 4, 1063-1128. https://doi.org/10.5194/gmdd-4-1063-2011.

Williams, J.W., Jackson, S.T., Kutzbach, J.E., 2007. Projected distributions of novel and disappearing climates by 2100 AD. Proc. Natl. Acad. Sci. U. S. A. 104, 5738-5742. https://doi.org/10.1073/pnas.0606292104.

Wollenberg, E., Richards, M., Smith, P., Havlík, P., Obersteiner, M., Tubiello, F.N., Herold, M., Gerber, P., Carter, S., Reisinger, A., van Vuuren, D.P., Dickie, A., Neufeldt, H., Sander, B.O., Wassmann, R., Sommer, R., Amonette, J.E., Falcucci, A., Herrero, M., Opio, C., Roman-Cuesta, R.M., Stehfest, E., Westhoek, H., Ortiz-Monasterio, I., Sapkota, T., Rufino, M.C., Thornton, P.K., Verchot, L., West, P.C., Soussana, J.-F., Baedeker, T., Sadler, M., Vermeulen, S., Campbell, B.M., 2016. Reducing emissions from agriculture to meet the $2{ }^{\circ} \mathrm{C}$ target. Glob. Chang. Biol. 22, 3859-3864. https:// doi.org/10.1111/gcb.13340.

Zazanashvili, N., Mallon, D., 2009. Status and Protection of Globally Threatened Species in the Caucasus. CEPF, WWF. Contour Ltd., Tbilisi, Georgia.

Zbicz, D.C., 2003. Imposing transboundary conservation. J. Sustain. For. 17, 21-37. https:// doi.org/10.1300/J091v17n01_03. 